\title{
Analisis Bahaya Titik Kendali Kritis Proses Pengolahan Bola-Bola Daging di Instalasi Gizi Rumah Sakit
}

\author{
Hazard Analysis and Critical Control Point Meat Balls Making Process in \\ Installation of Nutrition in Hospital
}

\author{
Inoy Trisnaini
}

Bagian Kesehatan Lingkungan Fakultas Kesehatan Masyarakat Universitas Sriwijaya

\begin{abstract}
Abstrak
Pada simpul lingkungan terdapat beberapa media yang dapat menjadi transmisi penularan penyakit, salah satunya melalui makanan. Bola-bola daging dengan bahan utama daging sapi merupakan salah satu makanan yang dibuat di Instalasi Gizi Rumah Sakit Umum Pusat (RSUP) dr. Mohammad Hoesin Palembang. Bahan pangan hewani merupakan sumber utama bakteri penyebab infeksi dan intoksikasi termasuk Salmonella sp. dan Escherichia coli. Bola-bola daging rentan mengalami kontaminasi oleh bahaya fisik, biologi, maupun kimia. Tujuan dari penelitian ini ialah analisis bahaya dan titik kendali kritis terhadap proses pengolahan bola-bola daging. Penelitian ini merupakan penelitian deskriptif kualitatif. Sumber informasi terdiri atas enam orang informan. Penelitian dilakukan dengan metode wawancara mendalam dan observasi. Instrumen yang digunakan ialah peralatan pengujian angka paling mungkin Escherichia coli dan Salmonella sp., pedoman wawancara mendalam, checklists, dan kamera. Hasil penelitian menunjukkan bahwa titik kendali kritis dalam proses pengolahan bola-bola daging terletak pada tahap penerimaan daging giling, penyimpanan bahan makanan basah, pengadonan dan pembentukan adonan, perebusan, penirisan, serta penyajian. Meskipun hasil penelitian menunjukkan bahwa secara fisik bola-bola daging dinilai baik dan kandungan Escherichia coli dan Salmonella sp. pada bola-bola daging ialah negatif, yang menjadi titik tekan adalah potensi bahaya biologi berupa bakteri patogen dan bahaya kimia nitrit nitrat.
\end{abstract}

Kata kunci: Bola-bola daging, kontaminasi, pengolahan makanan, titik kendali kritis

\footnotetext{
Abstract

In the knot environment there are some medias that could transmit disease, one of them is food. Meatballs with beef as main ingredient is one of food that is made in The Installation Nutrition RSUP dr. Mohammad Hoesin Palembang. Meats are the main source of bacteria that cause infections and intoxications, such as Salmonella and Escherichia coli. Meatballs are so vul-
}

nerable to get contaminated by physical, biological, or chemical hazards. The purpose of this research is hazard analysis and critical control point at meatballs making. This research is descriptive qualitative research. Sources of information consists of six informants. Methods of research conducted is in-depth interview and observation. The instrument used is the test equipment NER Escherichia coli and Salmonella, in-depth interview guidelines, checklists, and camera. The results showed that the critical control points in meatballs making is acceptance of minced beef, wet food storage, kneading and forming the dough, boiling, draining, and presentation. Although based on the observation and interviews indicated that physically meatballs were good and E. coli and Salmonella in meatballs were negative, the stress point is the potential dangers of biological pathogens and chemicals nitrite nitrate.

Key words: Meat balls, contamination, food processing, critical control point

\section{Pendahuluan}

Dewasa ini masalah keamanan pangan sudah merupakan masalah global, sehingga mendapat perhatian utama dalam penetapan kebijakan kesehatan masyarakat. Letusan penyakit akibat pangan (foodborne disease) dan kejadian-kejadian pencemaran pangan terutama yang disebabkan oleh bakteri patogen, terjadi tidak hanya di berbagai negara berkembang yang kondisi sanitasi dan higiene umumnya buruk, tetapi juga di negara-negara maju. Hal ini masih menjadi masalah yang serius di berbagai negara termasuk Indonesia. ${ }^{1}$

Kejadian penyakit yang ditularkan melalui makanan

Alamat Korespondensi: Inoy Trisnaini, Bagian Kesehatan Lingkungan FKM Universitas Sriwijaya Gd. Dr. A. I. Mutholib Kampus Unsri Indralaya Ogan Ilir Palembang Sum-Sel, Hp.085268260960, e-mail:voleta3009@gmail.com 
di Indonesia juga terbilang cukup tinggi, terlihat dari penyakit infeksi seperti tipus, kolera, disentri, dan tuberkulosis (TBC) yang masih tinggi dengan lebih dari 90\% kasus keracunan pangan ini disebabkan oleh kontaminasi mikroba. ${ }^{2}$

Bahan pangan yang berasal dari hewan merupakan sumber utama bakteri penyebab infeksi dan intoksikasi. Adapun beberapa bakteri yang biasa hidup pada produk daging ialah Salmonella, Campylobacter, Clostridium perfringens, Escherichia coli, Yersinia entercolitica, Listeria monocytogenes, Bacillus cereus, dan Staphilococcus aureus. ${ }^{3}$ Akibat dari bakteri-bakteri patogen ini tidak hanya berupa gejala-gejala ringan seperti mual dan muntah, tetapi juga dapat menimbulkan akibat yang fatal, seperti Bacillus cereus yang dapat menyebabkan diare akut yang bisa berakibat pada kematian dan bakteri Salmonella yang dapat membahayakan jiwa terutama pada anak-anak, orang lanjut usia, serta orang yang mengalami gangguan sistem kekebalan tubuh. ${ }^{1}$

Seperti umumnya rumah sakit menjadi tempat hidup berbagai macam bakteri patogen. ${ }^{4}$ Rumah Sakit Umum Pusat (RSUP) dr. Mohammad Hoesin, rumah sakit pemerintah terbesar di Kota Palembang, dituntut untuk memberikan pelayanan terbaik, termasuk dalam penyelenggaraan makanan. RSUP dr. Mohammad Hoesin Palembang banyak menyediakan menu khusus bagi pasien dengan dietnya masing-masing. Salah satu makanan yang diberikan kepada pasien ialah bola-bola daging. Proses pengolahannya, terutama pada penggilingan daging, sangat potensial menyebarkan mikroorganisme sehingga bola-bola daging pada akhirnya dapat menjadi produk daging yang berisiko bagi kesehatan. Untuk itu, perlu dilakukan pengawasan terhadap proses pengolahan makanan terkhusus pada makanan produk olahan daging dengan penerapan analisis bahaya titik kendali kritis yang merupakan suatu sistem yang mengidentifikasi, mengevaluasi, dan mengendalikan bahaya yang signifikan bagi sistem keamanan makanan. ${ }^{5}$

Tujuan penelitian ini adalah menganalisis bahaya titik kendali kritis proses pengolahan bola-bola daging di Instalasi Gizi RSUP dr. Mohammad Hoesin Palembang tahun 2010 sebagai upaya penerapan analisis bahaya titik kendali kritis di RSUP dr. Mohammad Hoesin Palembang.

\section{Metode}

Penelitian ini merupakan penelitian deskriptif dengan pendekatan kualitatif. Sumber informasi terdiri atas enam informan. Penelitian ini dilakukan dengan metode wawancara mendalam, pengujian kandungan Escherichia coli dan Salmonella, serta observasi. Penelitian ini juga menggunakan metode photovoice, yaitu dengan menerangkan berdasarkan gambar/foto yang tertera mengenai penerapan analisis bahaya titik kendali kritis dalam proses pengolahan bola-bola daging. Metode analisis keakutan dan risiko bahaya, metode penentuan signifikansi bahaya, serta diagram pohon keputusan penentuan titik kendali kritis juga digunakan dalam penelitian ini. ${ }^{6}$

Data primer dalam penelitian ini berupa data hasil pengujian Escherichia coli dan Salmonella, hasil observasi, dan wawancara mendalam. Data sekunder dalam penelitian ini berupa buku profil Instalasi Gizi RSUP dr. Mohammad Hoesin Palembang tahun 2009; daftar menu makanan pasien kelas I, II, dan III; daftar kebijakankebijakan RSUP dr. Mohammad Hoesin Palembang yang berkaitan dengan aspek analisis bahaya titik kendali kritis; dan telaah dokumen terkait lainnya.

\section{Hasil}

\section{Deskripsi Produk Bola-Bola Daging}

Bola-bola daging merupakan produk siap saji atau dapat langsung dikonsumsi saat bola-bola daging disajikan kepada pasien. Bola-bola daging terbuat dari daging sapi mentah giling, telur ayam, tepung terigu, bawang putih, bawang merah, dan ketumbar. Bola-bola daging diperuntukkan bagi pasien dari semua kalangan, usia, dan kelas sehingga baik pasien anak-anak maupun dewasa dan pasien kelas III sampai dengan kelas I dengan diet tinggi kalori dan tinggi protein dapat mengonsumsinya. Bolabola daging yang telah dimasak dan siap dikonsumsi mampu bertahan dan tetap dalam kondisi layak konsumsi selama kurang lebih 7 jam pada suhu kamar dan kurang lebih 1 × 24 jam pada suhu $4^{\circ} \mathrm{C}$ dalam lemari pendingin. Karakteristik dari bola-bola daging yang tampak secara fisik, yaitu berwarna coklat kehitaman, berbentuk bulat, dan beraroma khas semur. Bola-bola daging memiliki rasa seperti produk berbahan dasar daging dengan rasa khas daging. Berdasarkan hasil wawancara dan observasi, diketahui urutan-urutan sistematis dari alur proses pengolahan bola-bola daging (Gambar 1).

\section{Analisis Bahaya Fisik, Biologi, dan Kimia}

Bahaya fisik yang dinilai potensial untuk muncul adalah pada tahap penumisan. Bahaya fisik yang bersumber dari peralatan penggorengan yang digunakan, berupa kerak-kerak sisa makanan yang menempel. Bahaya biologi yang potensial muncul berupa bakteri patogen. Potensi kontaminasi bakteri patogen terdapat pada daging giling pada tahap penerimaan bahan makanan; daging, bumbu, dan bawang giling pada tahap penyimpanan; adonan bola-bola daging pada tahap pembuatan dan pembentukan adonan; adonan bola-bola daging yang telah jadi dan akan melalui tahap perebusan, bola-bola daging yang telah direbus dan sedang ditiriskan; bolabola daging yang telah dimasak sempurna; dan sedang 


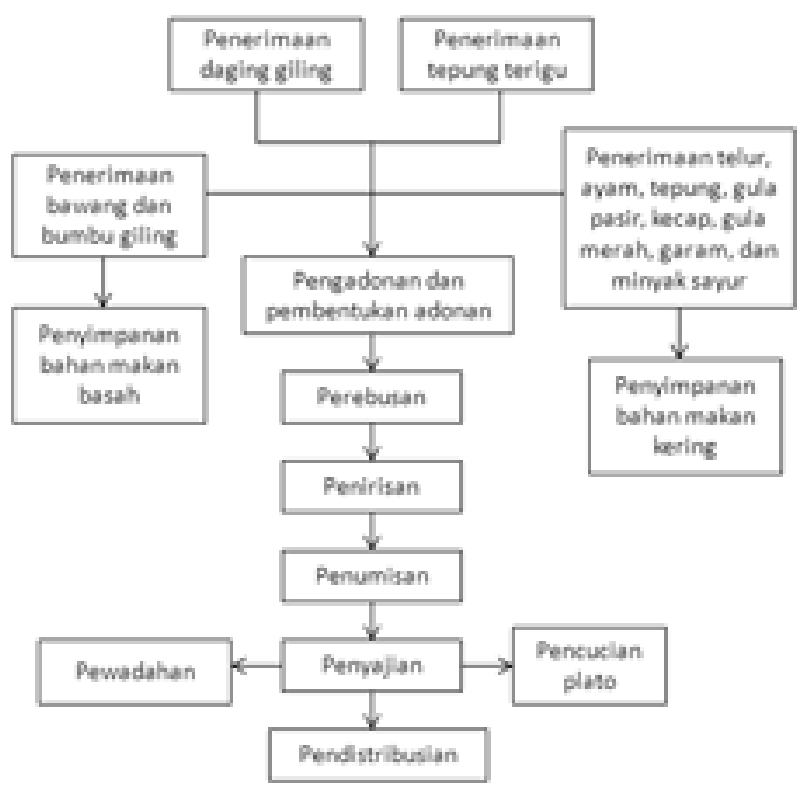

Gambar 1. Diagram Alur Proses Pengolahan Bola-Bola Daging

disajikan. Selain itu, juga terdapat bahaya kimia, yakni potensi terkandung bahan kimia nitrat dan nitrit yang ditambahkan pada daging giling sebagai bahan pewarna dan pengawet.

\section{Penentuan Titik Kendali Kritis}

Terdapat enam titik kendali kritis dari proses pengolahan bola-bola daging, yaitu tahap penerimaan daging giling, penyimpanan bahan makanan basah, pengadonan dan pembentukan adonan, perebusan, penirisan, dan tahap penyajian.

Batas kritis yang digunakan adalah parameter bakteriologis, suhu, penampilan visual, serta parameter penciuman. Beberapa batas kritis yang telah diterapkan oleh instalasi gizi, yaitu 1) kandungan angka paling mungkin (APM) Escherichia coli $<3 / \mathrm{g}$ dan Salmonella $s p$ negatif/25g makanan; 2) fisik barang saat penerimaan dalam kondisi baik; 3) total coliform (APM)/100 ml air $=0$; 4) perebusan menggunakan air yang telah mendidih; 5) penanganan yang higienis, yaitu menggunakan alat pelindung diri (APD) sarung tangan, celemek, dan penutup kepala; 6) bahan makanan segar, termasuk daging giling disimpan sementara dalam lemari pendingin dengan suhu $0^{\circ} \mathrm{C}-5^{\circ} \mathrm{C} ; 7$ ) bahan makanan kering disimpan di dalam ruangan dengan suhu $19^{\circ} \mathrm{C}-$ $20^{\circ} \mathrm{C}$.

Bentuk pemantauan yang telah diterapkan oleh pihak instalasi gizi selama ini terdiri atas pemantauan oleh pihak eksternal dan internal unit gizi tersebut. Pemantauan eksternal berupa pemeriksaan bakteriologis rutin pada air. Hal ini dilakukan untuk memantau apabila terdapat bakteri patogen pada air dapat segera diambil tindakan perbaikan. Pemantauan internal berupa pemantauan penggunaan APD oleh pekerja. Frekuensi dari pemantauan internal masih bersifat insidental dan belum terjadwal dengan rutin.

Beberapa tindakan perbaikan yang telah dilakukan oleh pihak instalasi gizi antara lain pengembalian produk yang rusak/berkualitas buruk untuk diganti dengan yang baik oleh supplier, pemberian teguran dan peringatan pada penjamah makanan yang tidak menggunakan APD pada saat mengerjakan pengolahan makanan, pengaturan suhu lemari pendingin dan ruang penyimpanan bahan makanan, penggunaan wadah tertutup, pencucian plato segera setelah digunakan oleh pasien dengan menggunakan sabun dan air hangat dan penambahan chlorin pada plato yang digunakan oleh pasien penyakit menular, pemberian kaporit pada tempat penampungan air apabila hasil laboratorium menunjukkan bahwa kondisi air tidak baik, perebusan adonan bola-bola daging dengan menggunakan air bersuhu $\pm 100^{\circ} \mathrm{C}$ atau air yang telah mendidih, serta peningkatan higiene sanitasi dalam proses pengolahan makanan.

Tindakan verifikasi yang dilakukan ialah berupa pemeriksaaan bakteriologis terhadap kandungan bakteri patogen Escherichia coli dan Salmonella sp. Pemeriksaan dilakukan di Balai Besar Laboratorium Kesehatan Palembang dan sejauh ini pemeriksaan yang dilakukan sebatas pemeriksaan bakteriologis.

Secara fisik, bola-bola daging dinilai berkualitas baik, sebab tidak ditemukan bahaya berupa benda/zat asing seperti batu-batu kecil pada bola-bola daging. Selain itu, bola-bola daging juga selalu disajikan dalam keadaan panas dan tidak rusak atau basi. Berdasarkan hasil pengujian diketahui kandungan Escherichia coli dan Salmonella dalam bola-bola daging adalah negatif. Secara kimia, dianalisis potensi kandungan bahan kimia nitrat dan nitrit di dalam daging giling yang dapat ditambahkan sebagai bahan pewarna dan pengawet.

\section{Pembahasan}

Pada tahap penumisan, pekerja menggunakan alat penggorengan yang baru selesai digunakan tanpa pencucian terlebih dahulu, sehingga sisa-sisa makanan tertinggal pada alat pengggorengan. Sisa-sisa tersebut dapat menempel pada bola-bola daging pada saat pemasakan dan menjadi bahaya fisik yang dapat mengontaminasi bola-bola daging. Seperti penelitian sebelumnya, ${ }^{7}$ terdapat bahaya fisik akibat alat penggorengan yang digunakan tidak dibersihkan terlebih dahulu setelah digunakan. Kerak makanan dapat mengubah rasa makanan, bahkan mengganggu tenggorokan begitu tertelan.

Selanjutnya, bahaya biologi berpotensi muncul pada tahap penerimaan daging sapi ataupun dari proses se- 
belum penerimaan seperti pada saat penggilingan. Semua daging yang berasal dari rumah potong hewan dan pasar tradisional ternyata telah terkontaminasi Escherichia coli. ${ }^{8}$ Penelitian lain pada bola-bola daging dengan uji mikrobiologi yang menghasilkan kandungan mikroorganisme yang mengontaminasi bahan daging mentah yang mengindikasikan bahwa daging hewan berpotensi besar terkontaminasi bakteri. ${ }^{9}$

Potensi kontaminasi bahaya biologi bakteri patogen juga terdapat pada tahap penyimpanan bahan makanan basah, baik pada bawang, bumbu, dan terutama daging giling. Selanjutnya, bahaya biologi dari bakteri potensial terdapat pada tahap pengadonan dan pembentukan adonan bola-bola daging. Sumber bahaya dapat berasal dari tangan penjamah akibat kontaminasi silang disebabkan penjamah tidak menggunakan sarung tangan atau juga dapat berasal dari peralatan stainless steel yang digunakan sebagai wadah. Kontaminasi silang pada makanan akibat kontaminasi tangan pengolah oleh Escherichia coli dilaporkan sekitar 12,5\%.10 Peralatan yang sering menjadi sumber kontaminasi pada makanan adalah stainless steel box.

Tahap perebusan juga berpotensi menyebabkan kontaminasi bahaya biologi dari bakteri, pada saat memasukkan adonan bola-bola daging pada panci perebusan penjamah tidak menggunakan sarung tangan atau alat bantu sendok sehingga berpotensi terjadi kontaminasi silang dari tangan penjamah. Bahaya biologi yang terdapat pada tahap penirisan berasal dari lingkungan sekitar wadah penirisan yang tidak bersih dan dari peralatan stainless steel yang digunakan sebagai wadah. Kondisi higiene sanitasi lingkungan yang buruk akan mempertinggi jumlah angka kuman pada makanan yang diproduksi yang menguatkan potensi bahaya biologi bakteri akibat sanitasi lingkungan yang kurang higiene. ${ }^{13}$

Terakhir, bahaya biologi terdapat pada tahap penyajian, bakteri dapat berasal dari lingkungan sekitar akibat wadah yang tidak tertutup pada saat pembagian makanan per ruang, plato yang digunakan sebagai wadah, serta air yang digunakan untuk mencuci plato dan peralatan lainnya. Terdapat korelasi yang bermakna antara cara pencucian alat dengan angka kuman pada makanan. ${ }^{14}$

Bahaya lain yang berpotensi terjadi pada proses pengolahan bola-bola daging ialah bahaya kimia yang berasal dari dua sumber, yaitu alat penggorengan yang berkarat dan terkelupas serta bahan kimia nitrit dan nitrat yang berpotensi terkandung di dalam daging giling sebagai bahan pewarna dan pengawet. Nitrit dan nitrat berbahaya karena dapat berikatan dengan amino dan anida yang terdapat pada protein daging dan membentuk turunan nitrosamin yang bersifat toksik. Nitrosamin merupakan salah satu senyawa yang diduga dapat menimbulkan kanker. ${ }^{15}$ Pemberian nitrat dan nitrit sebagai bahan tam- bahan pada makanan bukan merupakan hal yang baru. Salah satu contohnya adalah nitrat dan nitrit yang ditambahkan pada daging burger. ${ }^{16}$

\section{Penentuan Titik Kendali Kritis}

Adapun enam titik kendali kritis terdapat pada tahap penerimaan daging, penyimpanan bahan, pembuatan dan pembentukan adonan, perebusan, dan penirisan. Bahaya yang terkandung pada tahap penerimaan daging giling adalah bahaya biologi berupa bakteri patogen dan bahaya kimia yang berasal dari nitrat dan nitrit. Tindakan pengendalian yang dilakukan berupa penerapan spesifikasi bahan makanan untuk menjamin bahwa daging giling yang diterima berkualitas baik.

Bahaya pada tahap penyimpanan bahan makanan basah adalah bahaya biologi bakteri dan tindakan berupa pengaturan suhu lemari pendingin menjadi $4^{\circ} \mathrm{C}$ dan mengatur penempatan bahan makanan basah di dalam lemari pendingin.

Pada tahap pembuatan dan pembentukan adonan terdapat potensi bahaya biologi dari bakteri sehingga tindakan pengendalian bahaya dilakukan dengan pembersihan ruangan dapur secara rutin dan pendisiplinan dalam penerapan standar operasional prosedur (SOP) atau yang disebut dengan prosedur tetap (protap) saat pengolahan makanan.

Kemudian, tahap perebusan. Pada tahap ini terdapat bahaya yang juga berupa bakteri. Tindakan pengendalian dilakukan dengan pemberian APD berupa sarung tangan disertai pemantauan yang dilakukan untuk mencegah pekerja yang tidak menggunakan APD. Pengendalian juga dilakukan dengan menggunakan air yang telah mendidih untuk perebusan bola-bola daging. Tindakan tersebut sesuai dengan penelitian yang dilakukan oleh Widaningrum dan Christina Winarti, 17 mengenai tindakan pengendalian yang dilakukan pada tahap perebusan ekstrak sari apel dengan menggunakan air yang telah matang atau mendidih, sebab secara umum air yang terlihat sudah mendidih dinilai hampir mencapai suhu $100^{\circ} \mathrm{C}$.

Tahap penirisan dengan kondisi udara dan lingkungan yang kurang bersih berpotensi menyebabkan bahaya biologi. Untuk mengendalikan bahaya biologi pada tahap ini, sanitasi alat dan lingkungan ditingkatkan, salah satunya dengan menggunakan penutup pada wadah bola-bola daging serta meletakkan wadah di tempat yang cukup tinggi seperti di atas meja dan cukup berjarak dari lalulalang orang sehingga bahaya debu/kotoran bakteri yang mengontaminasi dapat dihindarkan.

Sumber kontaminasi bahaya biologi bakteri pada tahap penyajian adalah kondisi higiene sanitasi lingkungan yang kurang dan air yang digunakan untuk mencuci. Kondisi ini dapat dikendalikan dengan pendisiplinan penerapan higiene sanitasi, yaitu dengan menutup wadah 


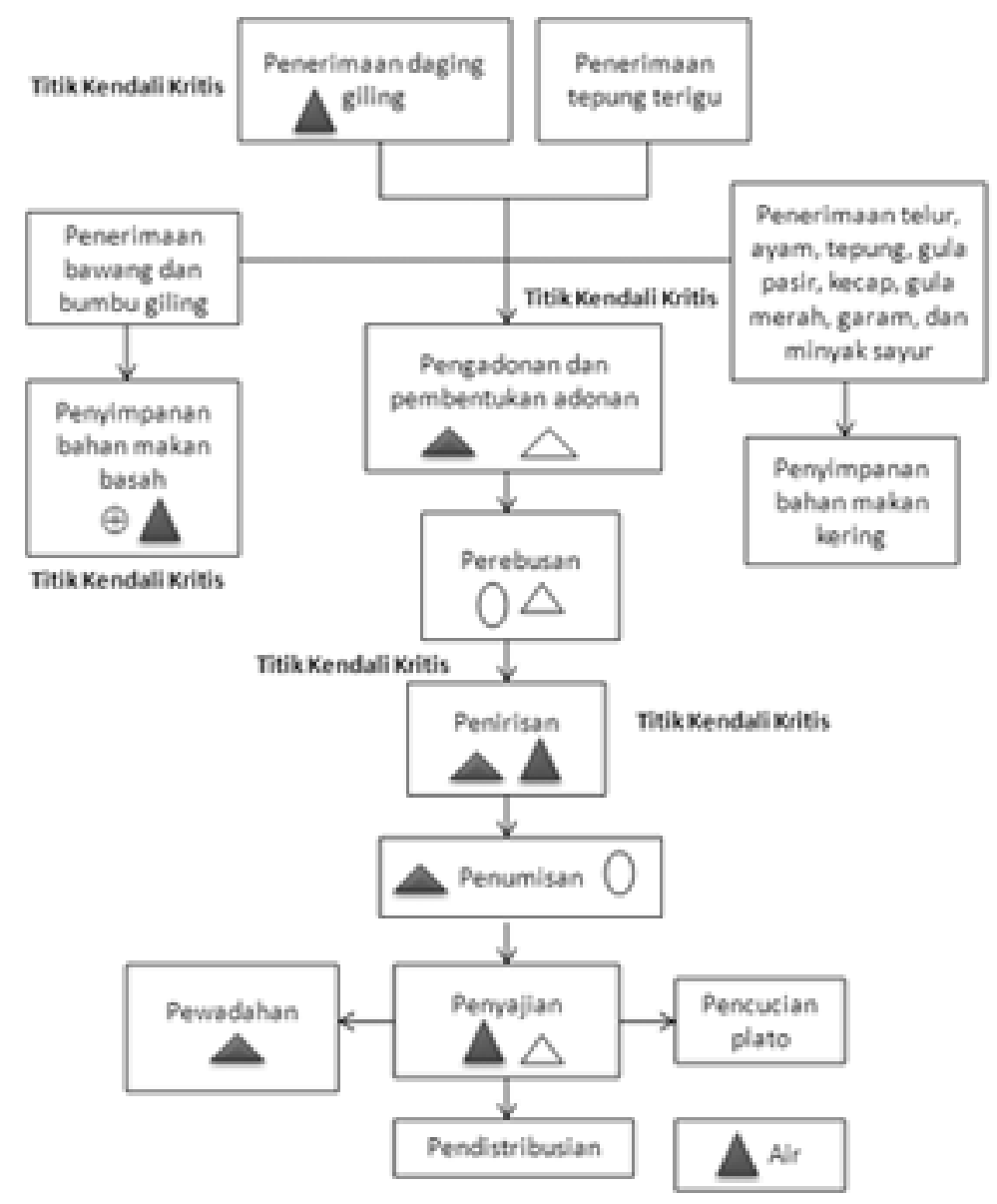

Gambar 2. Bagan Alur Proses Pengolahan Bola-Bola Daging dan Penilaian Titik Kendali Kritis

bola-bola daging, menggunakan sendok atau sarung tangan, dan menggunakan air hangat pada tahap pencucian peralatan masak. Selain itu, dilakukan pula pemberian kaporit pada air yang ditemukan kandungan bakteri. Penambahan klorin dalam pencucian plato untuk plato yang digunakan oleh pasien dengan penyakit menular seperti HIV juga perlu dilakukan. Terakhir, penting dilakukan pemeriksaan secara rutin kandungan bakteri pada air yang digunakan.

Penelitian lain menetapkan tahap pengadonan dan pembentukan adonan tidak termasuk titik kendali kritis pada proses pengolahan bakso ayam, tetapi sebagai salah satu tahapan dalam proses pengolahan yang berpotensi menyebabkan kontaminasi bahaya. ${ }^{18}$ Alur proses pengolahan bola-bola daging beserta titik kendali kritis disertakan dalam bagan (Gambar 2).

Beberapa batas kritis yang dapat digunakan dalam proses pengolahan bola-bola daging berdasarkan sumber standar-standar baku, literatur, maupun saran dari para pakar antara lain: 1) kandungan APM Escherichia coli < 3/g dan Salmonella sp negatif/25g makanan; 2) keadaan fisik barang saat penerimaan dalam kondisi baik, pada daging giling berwarna merah segar dan berbau khas daging serta pada bahan makanan kering masih tersimpan dalam kemasan dalam kondisi baik; 3) kandungan nitrat dalam daging yang tidak lebih dari 500 ppm dan nitrit tidak lebih dari $200 \mathrm{ppm}$; 4) total coliform (APM)/100 ml air ialah 0 ; 5) perebusan dengan menggunakan air bersuhu $>50^{\circ} \mathrm{C}$, atau air yang telah mendidih; 6) penanganan yang higienis menggunakan APD sarung tangan, celemek, dan penutup kepala; 7) bahan makanan segar, termasuk daging giling disimpan sementara dalam lemari pendingin dengan suhu $0^{\circ} \mathrm{C}-5^{\circ} \mathrm{C} ; 8$ ) bahan makanan kering disimpan di dalam ruangan atau lemari pendingin dengan suhu $19^{\circ} \mathrm{C}-20^{\circ} \mathrm{C}$; 9) tidak terjadi pencemaran ulang pada makanan akibat kontaminasi silang. ${ }^{1}$

Pemantauan, dalam konsep analisis bahaya titik kendali kritis, adalah tindakan dari pengujian atau observasi yang dicatat oleh unit usaha untuk melaporkan 
keadaan titik kendali kritis. ${ }^{6}$ Pada proses pengolahan bola-bola daging, tindakan pemantauan terhadap titik kendali kritis dilakukan dengan berbagai cara. Pertama, pengawasan yang dilakukan oleh subkoordinator penyelenggaraan makanan di instalasi gizi terhadap penggunaan APD. Namun, sistem pemantauan yang dilakukan saat ini masih bersifat manual dan belum terjadwal secara rutin serta tanpa menggunakan checklists.

Kedua, pemeriksaan alat masak yang dinilai telah rusak dan tidak layak digunakan lagi. Pemeriksaan dilakukan oleh koordinator di instalasi gizi termasuk oleh kepala instalasi gizi sendiri. Namun, pemeriksaan ini juga belum dilakukan secara rutin sehingga penggantian alat masak akan dilakukan apabila terdapat laporan pekerja atau penjamah makanan bahwa terdapat alat masak yang rusak.

Ketiga, pemeriksaan kandungan bakteri patogen pada air yang digunakan di instalasi gizi. Pemeriksaan dilakukan oleh Kementerian Kesehatan Republik Indonesia yang dilakukan secara rutin, setiap satu bulan sekali. Berdasarkan Peraturan Menteri Kesehatan Nomor 416 Tahun 1990, batasan jumlah maksimum kandungan bakteri patogen pada air adalah $0 / 100 \mathrm{ml}$. Terakhir, pemeriksaan kandungan bakteri patogen seperti Escherichia coli dan Salmonella pada plato (sampel usap alat). Pemeriksaan dilakukan oleh Kementerian Kesehatan Republik Indonesia pada Balai Besar Laboratorium Kesehatan Palembang setiap satu bulan sekali.

Tindakan perbaikan adalah tindakan yang harus diambil atau diputuskan berdasarkan hasil pemantauan terhadap titik kendali kritis yang mengindikasikan bahwa titik kendali kritis tidak terkendali. ${ }^{19}$ Beberapa tindakan perbaikan berikut dapat dilakukan untuk menghadapi penyimpangan-penyimpangan yang terjadi pada proses pengolahan bola-bola daging: 1) berbagai produk yang dinilai berkualitas buruk atau rusak dikembalikan pada pemasok untuk diganti dengan produk yang baru dan berkualitas baik; 2) dalam menerapkan protap yang berkaitan dengan APD sering kali terjadi pelanggaran. Untuk itu, peringatan terhadap penjamah makanan yang tidak menggunakan APD berupa celemek, sarung tangan, dan penutup kepala pada saat mengolah makanan perlu diberikan; 3) peningkatan higiene sanitasi dalam proses pengolahan makanan. Tindakan perbaikan dapat berupa penggunaan wadah tertutup untuk makanan, penempatan wadah makanan pada tempat yang relatif tinggi dari lantai, dan di tempat yang terjaga kebersihannya; 4) apabila ditemukan alat masak yang dianggap telah tidak layak untuk digunakan, kepala instalasi gizi diharuskan mengganti alat masak dengan yang baru; 5) untuk menjamin dan mengantisipasi bakteri pada plato yang akan digunakan, pencucian dilakukan menggunakan air hangat serta menggunakan cairan desinfektan, yaitu klorin untuk plato yang digunakan pasien yang menderita penyakit menular; 6) klorin atau bahan kimia lainnya diberikan apabila pemeriksaan bakteriologis terhadap air menemukan kandungan bakteri patogen dalam air yang digunakan di instalasi gizi; terakhir, 7) penyemprotan insektisida rutin per tiga hari untuk menghindari kontaminasi makanan oleh serangga dan hewan pengerat lain.

Verifikasi berdasarkan Standar Nasional Indonesia (SNI) 01-4852-1998 adalah penetapan metode, prosedur, pengujian, dan cara pendataan, serta pemantauan untuk menentukan kesesuaian dengan rencana analisis bahaya titik kendali kritis. ${ }^{20}$ Pihak Instalasi Gizi RSUP dr. Mohammad Hoesin telah menerapkan tindakan verifikasi berupa verifikasi internal bekerja sama dengan Kementerian Kesehatan Palembang melalui Balai Besar Laboratorium Kesehatan Palembang. 6

Persyaratan ketat untuk makanan jadi agar sehat dikonsumsi oleh konsumen meliputi makanan tidak rusak, busuk atau basi, memenuhi persyaratan bakteriologis sesuai ketentuan yang berlaku, harus bebas dari kuman Escherichia coli dengan angka kuman Escherichia coli pada minuman harus 0/100ml, tidak boleh mengandung residu bahan pestisida dan logam berat yang melebihi ambang batas yang diperkenankan menurut ketentuan yang berlaku. Kualitas keamanan pangan dapat dilihat dari parameter fisik, biologi, dan kimia, dan dikatakan baik jika aman secara ketiganya. ${ }^{21}$

Berdasarkan parameter fisik, kualitas bola-bola daging dapat dinilai baik. Hal ini disebabkan pada saat disajikan pada pasien bola-bola daging dalam keadaan baik, yaitu dalam kondisi panas dan tidak basi atau rusak. Selain itu, pada bola-bola daging juga tidak ditemukan material-material kecil seperti batu-batu kecil, helaian rambut, ataupun yang lainnya.

Berdasarkan hasil pengujian diketahui kandungan bakteri patogen Escherichia coli dan Salmonella pada bola-bola daging adalah negatif. Hal ini menunjukkan bahwa bola-bola daging sesuai dengan Peraturan Kepala Badan Pengawas Obat dan Makanan Republik Indonesia Nomor HK.00.06.1.52.4011 tentang Penetapan Batas Maksimum Cemaran Mikroba dan Kimia dalam Makanan yang menetapkan bahwa batasan cemaran bakteri patogen untuk jenis makanan daging olahan $<3 / \mathrm{g}$ untuk cemaran Escherichia coli dan Salmonella $s p$ negatif. Pada penelitian lain terhadap bakso daging sapi ditunjukkan kandungan Escherichia coli di atas ambang yang diperbolehkan (100 colony forming unit, CFU/g) meskipun secara fisik makanan tersebut bebas dari cemaran bahaya fisik seperti kerikil. ${ }^{22}$ Pada penelitian lain, pada produk akhir bola-bola daging ditemukan kandungan koliform $<3$ hingga $>2,400$ APM g. ${ }^{1,23}$

Berdasarkan parameter kimia, didapatkan analisis potensi bahaya kimia berupa kandungan nitrat dan nitrit 
dalam daging giling. Apabila bahan kimia nitrit dan nitrat benar-benar terkandung dalam daging giling dan berada di atas batas berdasarkan Peraturan Menteri Kesehatan Republik Indonesia Nomor 722 ialah 500 ppm untuk nitrat dan 200 ppm untuk nitrit, dapat menimbulkan bahaya bagi kesehatan. Untuk itu, perlu dilakukan pemeriksaan lebih lanjut mengenai kandungan bahan kimia nitrat dan nitrit di dalam daging giling.

\section{Kesimpulan}

Bola-bola daging merupakan salah-satu menu yang dihasilkan oleh Instalasi Gizi RSUP dr. Mohammad Hoesin yang dibuat dari bahan utama daging sapi. Berdasarkan hasil analisis bahaya titik kendali kritis, terdapat enam titik kendali kritis dari proses pengolahan bola-bola daging, yaitu tahap penerimaan daging giling, penyimpanan bahan makanan basah, pengadonan dan pembentukan adonan, perebusan, penirisan, dan tahap penyajian. Berdasarkan parameter fisik, bola-bola daging dinilai baik. Untuk parameter biologi berdasarkan pengujian di Balai Besar Laboratorium Kesehatan Palembang, diketahui kandungan bakteri patogen Escherichia coli dan Salmonella sp pada bola-bola daging adalah negatif. Untuk parameter kimia, diketahui potensi kontaminasi bahaya kimia nitrat dan nitrit yang ditambahkan dalam daging giling.

\section{Saran}

Saran yang dapat diberikan dari penelitian ini adalah unit Instalasi Gizi RSUP dr. Mohammad Hoesin perlu melakukan pengawasan rutin terhadap penggunaan APD oleh pekerja disertai pemberian APD yang nyaman bagi penjamah, pemeriksaan rutin terhadap peralatan masak, pembentukan tim audit internal yang bertanggung jawab terhadap pemantauan penerapan higiene sanitasi proses pengolahan makanan, pengadaan pelatihan-pelatihan higiene sanitasi, penerapan metode three compartment sink dalam pencucian plato sebagai metode yang terbukti efektif, serta pemeriksaan laboratorium mengenai kandungan bahan kimia nitrat dan nitrit dalam daging giling berkaitan dengan potensi kandungan bahan kimia nitrat dan nitrit di dalam daging giling.

\section{Daftar Pustaka}

1. Badan Pengawas Obat dan Makanan. Peraturan Kepala Badan Pengawas Obat dan Makanan Republik Indonesia Nomor hk.00.06.1.52.4011 tentang Penetapan Batas Maksimum Cemaran Mikroba dan Kimia Dalam Makanan. 2009 [diakses tanggal 1 Juni 2010]. Diunduh dari: http://www.pom.go.id.

2. Fhatonah S. Higiene dan sanitasi makanan. 2005 [diakses tanggal 12 Juni 2010]. Diunduh dari: http://www.unnes.ac.id.

3. Siagian A. Mikroba patogen pada makanan dan sumber pencemarannya. 2002 [diakses tanggal 30 Mei 2010]. Diunduh dari: http://www.library. usu.ac.id.
4. Hasbullah T. Pengendalian infeksi nosokomial di RS Persahabatan Jakarta. Cermin Dunia Kedokteran. 1993 [diakses tanggal 21 Mei 2010]. Diunduh dari: http://www.kalbe.co.id.

5. Putri ISS. Hazard analysis critical control point (HACCP ) yang perlu diketahui. 2010 [diakses tanggal 19 Maret 2010]. Diunduh dari: http://www.banyumaskab.go.id.

6. Winarno FG. HACCP dan penerapannya dalam industri pangan. Bogor: M-BrioPress; 2004.

7. Marbun AR. Manajemen proses pengolahan ayam goreng di rumah makan bersaudara [skripsi]. Palembang: Program Sarjana Fakultas Kesehatan Masyarakat Universitas Sriwijaya; 2008.

8. Sartika RAD, Indrawani YM, Sudiarti T. Analisis mikrobiologi escherichia coli pada hasil olahan hewan sapi dalam proses produksinya. Journal of Makara Kesehatan [online]. 2005 [diakses tanggal 5 Januari 2011]; 9 (1): 23-8. Diunduh dari: http://www.journal.ui.ac.id.

9. Pedroso DMM, Laria ST, Gamba RC, Heidtmann S, Lucia V, Rall M. Critical control points for meat balls and kibbe preparations in a hospital kitchen. Journal of Revista de Microbiologia [online]. 1999 [cited 2011 January 15]; 30 (4). Available from: http://www.scielo.br.

10. Djaja IM. Kontaminasi e. coli pada makanan dari tiga jenis tempat pengelolaan makanan (TPM) di Jakarta Selatan tahun 2003. Journal of Makara Kesehatan [online]. 2008 [diakses tanggal 5 Januari 2010]; 12 (1): 36-41. Diunduh dari: http://www.journal.ui.ac.id.

11. Gungor E, Nalan G. Determination of microbial contamination sources at a frankfurter sausage processing line. Journal of Tubitak [online]. 2008 [cited 2011 January 16]; 34-1-8-0805-28: 53-9. Available from: http://www.journals.tubitak.gov.

12. Barros MDA, Nero LA, Monteiro AA, Beloti V. Identification of main contamination points by hygiene indicator microorganisms in beef processing plants. Clencia e Tecnologia de Alimentos. 2007 [cited 2011 January 8]: 27 (4). Available from: http://www.scielo.br.

13. Rahayu NPS. Hubungan antara higiene sanitasi lingkungan warung dan praktek pengolahan mie ayam dengan angka kuman. 2007 [diakses tanggal 5 Januari 2010]. Diunduh dari: http://www.eprints.undip.ac.id.

14. Andriyani A, Gunawan IMA, Susilo J. Efektifitas penurunan jumlah angka kuman alat makan dan efisiensi biaya yang digunakan pada metode pencucian alat makan pada rumah sakit Kota Surakarta. Journal of Gizi Klinik Indonesia [online]. 2009 [diakses tanggal 6 Januari 2011]; 6 (1): 35-41. Diunduh dari: http://www.jurnal.pdii.lipi.go.id.

15. Husni E, Samah A, Ariati R. Analisa zat pengawet protein dalam makanan siap saji sosis. Jurnal Sanis dan Teknologi Farmasi [online]. 2007 [diakses tanggal 6 Januari 2011]; 12 (2): 108-11. Diunduh dari: http://www.digilib.unsri.ac.id

16. Cory M. Analisis kandungan nitrit dan pewarna merah pada daging burger yang dijual di grosir bahan baku burger di Kota Medan. 2009 [diakses tanggal 6 Januari 2011]. Diunduh dari http://www.repository. usu.ac.id.

17. Widaningrum, Winarti C. Studi penerapan HACCP pada proses produksi sari buah apel. 2007 [diakses tanggal 10 Desember 2010]. Diunduh dari: http://www.bsn.or.id.

18. Harmayani E, Santoso E, Utami T, Raharjo S. Identifikasi bahaya kontaminasi staphylococcus aureus dan titik kendali kritis pada pengolahan produk daging ayam dalam usaha jasa boga. Agritech. 2010 [diakses tanggal 6 Januari 2011]: 16 (3); 7-15. Diunduh dari: 
http://www.google.co.id.

19. Thaheer DIH. Sistem manajemen HACCP. Jakarta: PT Bumi Aksara; 2005.

20. Badan Standarisasi Nasional. Sistem analisa bahaya dan pengendalian titik kritis (HACCP) serta pedoman penerapannya. 1998 [diakses tanggal 12 Juni 2010]. Diunduh dari: http://www.ebookpangan.com.

21. Mukono HJ. Prinsip dasar kesehatan lingkungan. Surabaya: Airlangga University Press; 2006
22. Wijanarko G, Arsil P. Evaluasi bahaya dan penetapan titik kendali kritis pada pembuatan makanan jajanan yang dijual di kawasan wisata Baturaden Purwokerto. 2007 [diakses tanggal 10 Desember 2010]. Diunduh dari: http://www.jurnal.pdii.lipi.go.id.

23. Soriano JM, Rico H, Molto JC, Manes J. Microbial evaluation of spanish potato omelette and cooked meat samples in university restaurants. Journal of Food Protection [online]. 2000 [cited 2011 January 15]; 63 (9): 1273-6. Available from: http://www.ingentaconnect.com. 